\title{
FABRICATION AND CHARACTERIZATION OF A FEW SUBSTITUTED POLY (p-PHENYLENE VINYLENE) POLYMER
}

\author{
Gitalee Sharma \\ Department of Engineering Chemistry \\ Dibrugarh University Institute of Engineering and Technology, \\ Dibrugarh, Assam, India
}

\begin{abstract}
Single layered organic solar cell devices were fabricated with six substituted poly( $p$-phenylene-vinylene) (PPV) polymers as active layers. Small optical band gap and its bright yellow fluorescence make PPV a promising candidate in photovoltaics. UV-Visible studies performed and band gap calculated which ranged between $2.2-2.8 \mathrm{eV}$, showing their potential for use in photovoltaics. Photovoltaic devices were fabricated and J-V characteristics studied. Maximum power conversion efficiency (PCE) was observed for DG6 $(0.60 \%)$ followed by DG3 $(0.56 \%)$ with maximum fill factor of 0.43 and 0.41 respectively. Hence, modification in the fabrication techniques of the devices fabricated may increase its potential for showing higher power conversion efficiency.
\end{abstract}

Keywords - Poly(p-phenylene vinylene), Organic solar cells, Power Conversion Eficiency, Band Gap

\section{INTRODUCTION}

Organic solar cells have gained much attention over the years because of their easy fabrication and processability and ecofriendliness [1-4]. In this view different sandwich model of polymer active layers as single or double component (donor/acceptor pair) between two electrodes have been proposed [5]. However, the power conversion efficiency of these photovoltaic devices is still low compared to the conventional inorganic devices [6]. Latest reports reveal that the power conversion efficiency (PCE) of organic solar cells is only $8.4 \%$ in lab and tandem organic solar cell, $17.3 \%$, thereby opening up room for further research [7,8]. Poly $(p-$ phenylene vinylene) (PPV) and its derivatives have proved to be the only conducting polymers to be successfully processed in film with high crystallinity levels and which can be synthesized feasibly with good purity and high molecular weight [9]. The small optical band gap and bright yellow fluorescence make PPV a candidate in many electronic applications such as light-emitting diodes and photovoltaic devices $[10,11]$. Thus, a new range of substitution to PPV might prove to be a better compound for devising organic solar cells in terms of efficiency.

In this paper, we report the design and synthesis of six substituted poly(p-phenylene vinylene) conducting polymers, device fabrication with this new PPVs as single active layer and the study of their solar cell activity.

\section{METHODS AND MATERIALS}

\section{A. SYNTHESIS}

Six analogs of PPV was synthesized by reduction followed by in situ coupling. At first, acetylglycine was prepared by the traditional method [12]. Oxazolone was synthesized from acetylgylcine and three different aldehydes, benzaldehyde, naphthaldehyde and terephthaldehyde separately in bulk (Scheme 1) [12].

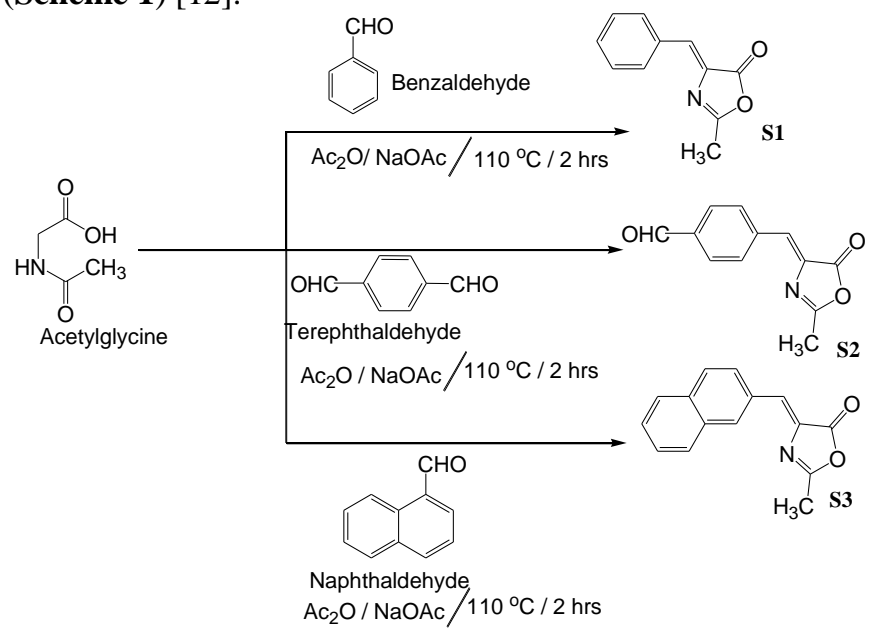

Scheme 1: Synthesis of oxazolone

The substituted polymers G1, G2 and G3 were then prepared using Poly(5-(3,7-dimethyloctyloxy)-2-methoxy-cyanoterephthalylidene (PPV1) as the starting polymer and three variety of synthesized oxazolones (S1,S2,S3). The other three substituted polymers G4, G5 and G6 were synthesized from Poly (5-(2- 


\section{International Journal of Engineering Applied Sciences and Technology, 2019 \\ Vol. 4, Issue 6, ISSN No. 2455-2143, Pages 129-132 \\ Published Online October 2019 in IJEAST (http://www.ijeast.com)}

ethylhexyloxy)-2-methoxy-cyanoterephthalylidene

(PPV2) and the same three oxazolones $(\mathrm{S} 1, \mathrm{~S} 2, \mathrm{~S} 3)$ as the starting material (Scheme 2). The products were obtained in $70-80 \%$ yield. IR, ${ }^{1} \mathrm{H}$ NMR and ${ }^{13} \mathrm{C}$ NMR were used to characterize the final products. Characterization showed the presence of the expected products.

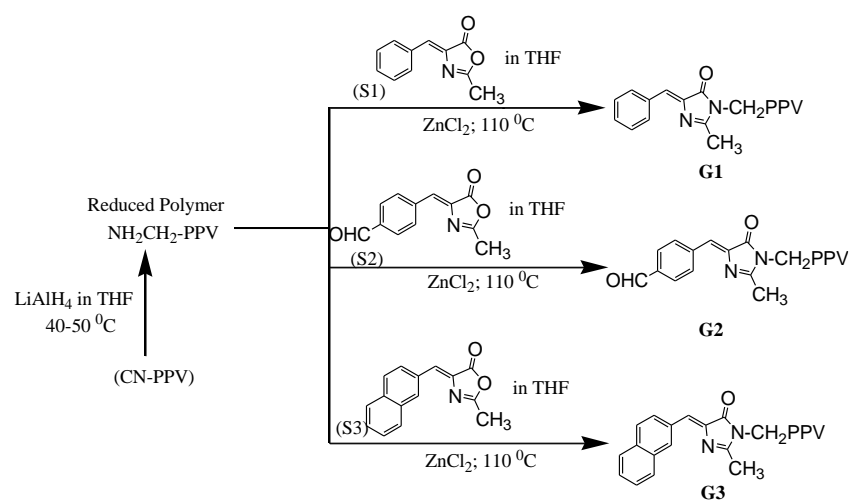

CN-PPV: Poly(5-(3,7-dimethyloctyloxy)-2- methoxy-cyanoterephthalylidene and

Poly(5-(2-ethylhexyloxy)-2-methoxy-cyanoterephthalylidene

Scheme 2: Complete synthesis of six substituted polymers

\section{B. DETECTION METHOD}

The purity of the compounds was checked by TLC Acetone /hexane, 1: 9). IR spectra of samples (solid powders) were recorded on a SHIMADZU IR spectrometer. ${ }^{1} \mathrm{H}$ and ${ }^{13} \mathrm{C}$ NMR spectra were obtained on JNM-ECS400 spectrometer with TMS as the internal standard and $\mathrm{CDCl}_{3}$ as the solvent. Elemental analysis was carried on a EuroEA Elemental Analyser. Melting points were determined on Melting Point Apparatus and are not corrected. UV-visible spectra were recorded on a Double Beam JASCO spectrophotometer in $2 \times 10^{-5} \mathrm{M} \mathrm{MeOH}$ solution.

\section{RESULTS AND DISCUSSION}

\section{A. UV-VISIBLE STUDIES}

UV-visible studies of the six substituted polymers in five solvents ((A: Chloroform; B: Cyclohexane; C: 1,3-Dioxan, D: Ethylacetate, E: Methanol) differing in their polarity was performed. The data generated is highlighted in Table 1 below.

The results of the UV-Visible studies showed that varying solvent polarity leads to the shift in the $\lambda_{\max }$ in the UV-Visible spectra of the same compound. It has been observed that as the polarity of the solvents increases, $\lambda_{\max }$ increases, which is visible from the red shift of all the synthesized products in methanol compared to the other solvents. This is because of the formation of H-bonds by methanol with the ground state of all the substituted PPV molecules. Further, from the UV- visible spectra the band gap for each of the substituted polymer was calculated. The band gap values ranged between 2.26-2.80eV showing potential for their use in photovoltaics as it is only (1.1-1.7) eV away from the band gap of silicon solar cells.

Table 1: UV-Visible characterization of six analogs in five different solvents varying in their polarity (A: Chloroform; B: Cyclohexane; C: 1,3-Dioxan, D: Ethylacetate, E: Methanol)

\begin{tabular}{|c|c|c|c|c|c|c|}
\hline Compd & Solvent & Conc & $\begin{array}{c}\text { Wavelength } \\
\lambda_{\max }(\mathrm{nm})\end{array}$ & $\begin{array}{c}\text { Absor- } \\
\text { bance }\end{array}$ & $\begin{array}{c}\text { Molar } \\
\text { extinction } \\
\text { coefficient } \\
\left(\mathrm{mol}^{-}\right. \\
\left.{ }^{1} \mathrm{Lcm}^{-1}\right)\end{array}$ & $\begin{array}{l}\text { Band } \\
\text { gap } \\
(\mathrm{eV})\end{array}$ \\
\hline \multirow[t]{5}{*}{ GS1 } & $\mathbf{A}$ & & 544 & 0.124 & 12400 & 2.28 \\
\hline & B & & 542 & 0.123 & 12300 & 2.29 \\
\hline & C & $1.0 \mathrm{x}$ & 543 & 0.122 & 12200 & 2.29 \\
\hline & D & $10^{-5}$ & 544 & 0.124 & 12400 & 2.28 \\
\hline & $\mathbf{E}$ & & 545 & 0.124 & 12400 & 2.27 \\
\hline \multirow[t]{5}{*}{ GS2 } & $\mathbf{A}$ & & 453 & 0.186 & 18600 & 2.74 \\
\hline & B & & 451 & 0.169 & 16900 & 2.75 \\
\hline & C & $1.0 \mathrm{x}$ & 447 & 0.231 & 23100 & 2.78 \\
\hline & D & $10^{-5}$ & 446 & 0.198 & 19800 & 2.79 \\
\hline & $\mathbf{E}$ & & 545 & 0.144 & 14400 & 2.27 \\
\hline \multirow[t]{5}{*}{ GS3 } & $\mathbf{A}$ & & 454 & 0.203 & 20300 & 2.54 \\
\hline & B & & 450 & 0.117 & 11700 & 2.57 \\
\hline & C & $1.0 \times$ & 450 & 0.152 & 15200 & 2.65 \\
\hline & D & $10^{-5}$ & 494 & 0.179 & 17900 & 2.39 \\
\hline & $\mathbf{E}$ & & 548 & 0.230 & 23000 & 2.25 \\
\hline \multirow[t]{5}{*}{ GS4 } & $\mathbf{A}$ & & 453 & 0.088 & 8800 & 2.74 \\
\hline & B & & 454 & 0.066 & 6600 & 2.74 \\
\hline & $\mathbf{C}$ & $1.0 \times$ & 445 & 0.082 & 8200 & 2.79 \\
\hline & D & $10^{-5}$ & 445 & 0.159 & 15900 & 2.79 \\
\hline & $\mathbf{E}$ & & 462 & 0.080 & 8000 & 2.69 \\
\hline \multirow[t]{5}{*}{ GS5 } & $\mathbf{A}$ & & 451 & 0.138 & 13800 & 2.75 \\
\hline & B & & 453 & 0.076 & 7600 & 2.74 \\
\hline & $\mathbf{C}$ & $1.0 \mathrm{x}$ & 447 & 0.220 & 22000 & 2.78 \\
\hline & D & $10^{-5}$ & 443 & 0.211 & 21100 & 2.80 \\
\hline & $\mathbf{E}$ & & 480 & 0.137 & 13700 & 2.59 \\
\hline \multirow[t]{5}{*}{ GS6 } & $\mathbf{A}$ & & 450 & 0.083 & 8300 & 2.75 \\
\hline & B & & 452 & 0.068 & 6800 & 2.74 \\
\hline & C & $1.0 \times$ & 448 & 0.086 & 8600 & 2.77 \\
\hline & D & $10^{-5}$ & 448 & 0.162 & 16200 & 2.77 \\
\hline & $\mathbf{E}$ & & 553 & 0.142 & 14200 & 2.23 \\
\hline
\end{tabular}

\section{A. DEVICE FABRICATION AND ELECTRICAL CHARACTERIZATION}

The photovoltaic devices were fabricated using the formula ITO (130nm) || WPTA (90nm) || PEDOT:PSS (60nm) \| Polymer layer (100nm) \| Al (100nm) (Fig.1). Indium tin oxide (ITO) coated glass substrate were cleaned sequentially in distilled water, acetone and 2-propanol in a sonic bath for 10 min at each step. The ITO glasses were then UV-O treated for 10 min. After cleaning, W-PTA were spin coated at 3000 rpm for $30 \mathrm{~s}$ and the sample was heated at $115^{\circ} \mathrm{C}$ for $15 \mathrm{~min}$. 


\section{International Journal of Engineering Applied Sciences and Technology, 2019 \\ Vol. 4, Issue 6, ISSN No. 2455-2143, Pages 129-132 \\ Published Online October 2019 in IJEAST (http://www.ijeast.com)}

PEDOT:PSS solution was then spin-coated on the W-PTA layer under the same conditions, and the sample was heated at $115{ }^{0} \mathrm{C}$ for $15 \mathrm{~min}$. The substituted PPV layer was spin coated on top of the PEDOT: PSS layer. After spin-coating the active layer, an $\mathrm{Al}$ cathode was deposited at $100 \mathrm{~nm}$ under a $2 \times 10^{-6}$ Torr vacuum in the thermal evaporator.

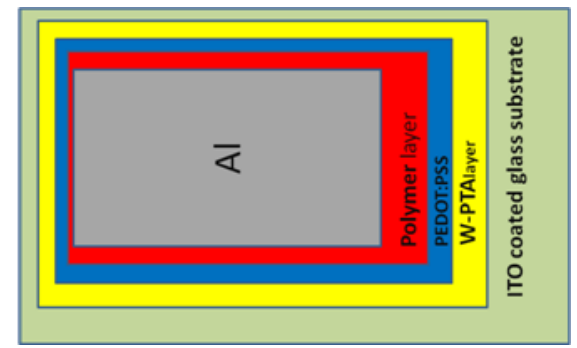

Fig. 1: Schematic of the devices fabricated

The thickness of the layers in the organic photovoltaic devices was measured by the weighing method. The current-voltage (J$\mathrm{V})$ characteristics of the photovoltaic solar cell were measured using a Keithley model 2420 sourcemeter under day sunlight of $100 \mathrm{~mW} / \mathrm{cm} 2$ illumination. The solar illumination was measured by using a lux meter.

In this study, the film thickness of the W-PTA and PEDOT:PSS layer was controlled by varying the weight percent of their solutions during the spin-coating process while all other experimental conditions, such as rpm (3000rpm) for 30s and annealing temperature $\left(115^{\circ} \mathrm{C}\right)$, were fixed. The spin coating rpm of the polymer layer was maintained at $1000 \mathrm{rpm}$ for $60 \mathrm{~s}$. The table $\mathbf{2}$ below shows a comparison of the $\mathrm{J}-\mathrm{V}$ characteristics of the photovoltaic devices fabricated with six different substituted PPVs.

Table 2: Comparison of the $\mathrm{J}-\mathrm{V}$ characteristics of the fabricated devices

\begin{tabular}{|c|c|c|c|c|c|}
\hline Devices & $V_{\text {oc }}[\mathrm{V}]$ & $\mathbf{J}_{\mathbf{s c}}[\mathbf{m A}$ & $\begin{array}{l}\text { Fill } \\
\text { Factor }\end{array}$ & $\left(\mathbf{P}_{\max }\right)$ & $\begin{array}{l}\text { PCE } \\
(\eta[\%])\end{array}$ \\
\hline DG1 & 0.46 & 2.50 & 0.45 & 0.52 & 0.55 \\
\hline DG2 & 0.44 & 2.05 & 0.38 & 0.34 & 0.36 \\
\hline DG3 & 0.47 & 2.75 & 0.41 & 0.53 & 0.56 \\
\hline DG4 & 0.41 & 1.74 & 0.35 & 0.25 & 0.26 \\
\hline DG5 & 0.42 & 1.80 & 0.38 & 0.28 & 0.30 \\
\hline DG6 & 0.47 & 2.80 & 0.43 & 0.58 & 0.60 \\
\hline
\end{tabular}

It has been observed that the PCE of DG6 $(0.6 \%)$ is the highest followed by DG3 $(0.56 \%)$. This is because this two substituted PPV have the same substituent attach to it. The structure of the substituent as shown below in scheme 2 shows the high rate of conjugation in the naphthalene substituent as compared to the other PPVs synthesized by us. The WPTA layer in between the ITO and PEDOT: PSS layer could function as a stairway for hole transport in polymer solar cells. The J-V curve for the device DG6 is shown in fig. 2.

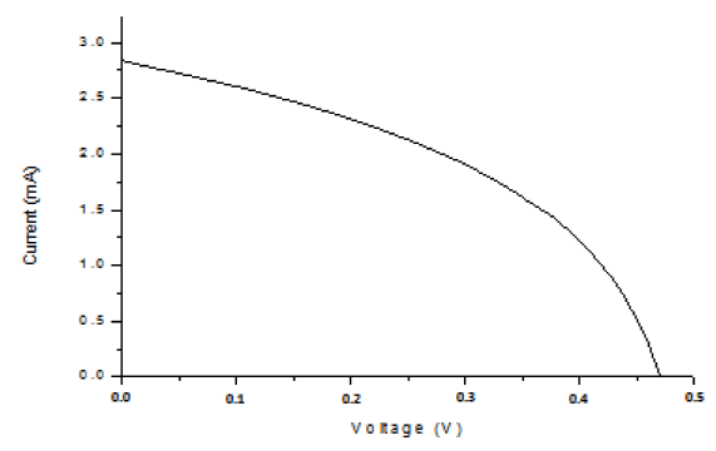

Figure 2: J-V curve for the device DG6

\section{CONCLUSION}

The paper reports the synthesis of six substituted $p$-phenylene vinylene polymer with two different cyano PPVs. The synthesis of the substituted polymer introduces a new methodology of in situ reduction of the nitrile group to the amine group which in turn couples with the already synthesized oxazolone to form the final product. This methodology is effective as it reduces the use of solvents in stepwise reactions and results in an appreciable yield of 70$80 \%$. Photovoltaic devices were fabricated with the newly substituted polymers as active layer and their J-V characterizationdone. The electrical studies showed that of all the six devices, device DG6 showed the highest power conversion efficiency of $\mathbf{0 . 6 \%}$ followed by DG3 of $\mathbf{0 . 5 6 \%}$ thereby, showing potential for use as organic solar cells. Further improvements in the PCE of the devices is possible through modification in the device fabrication techniques mainly the spin coating methods.

\section{ACKNOWLEDGEMENT}

The authors would like to acknowledge All India Council for Technical Education (AICTE), New Delhi, India for financial support and Department of Physics and Department of Chemistry, Dibrugarh University for providing lab facility for a few experiments.

\section{REFERENCE}

[1] Regan B.O'., and Gratzel M. (1991). A Low-Cost, HighEfficiency Solar Cell Based on Dye-Sensitized Colloidal TiO2 Films, in Nature, (pp.737-740).

[2] Gunes S., Neugebauer H., and Sacriciftci N.S. (2007). Conjugated Polymer-Based Organic Solar Cells, in Chem Rev., (pp.1324-1338).

[3] Brasec C. J., Gowrisanker S., Halls J. J. M., Laird D., Jia S. J., and Williams S. P. (2010). Polymer-Fullerene Bulk 
Heterojunction Solar Cells, in Adv. Mater., (pp. 38393856).

[4] Izawa S.,. Hashimoto K., and Tajima K. (2011). Efficient Charge Generation And Collection in Organic Solar Cells Based on Low Band Gap Dyad Molecules, in Chem Commun., (pp. 6365-6367).

[5] Zheng Y., Huang J., Wang G., Kong J., Huang D., Beromi M. M., Hazari N., Taylor A. D., and Yu J. (2018). A Highly Efficient Polymer Non-Fullerene Organic Solar Cell Enhanced by Introducing a Small Molecule as a Crystallizing-Agent, in Materials Today, (pp. 79-87).

[6] Bagher A.M. (2014). Comparison Of Organic Solar Cells And Inorganic Solar Cells, in International Journal of Renewable and Sustainable Energy, (pp.53-58).

[7] Cnops K., Rand B. P., Cheyns D., Vereet B., Empl M. A., and Heremans P. (2014). 8.4\% Efficient Fullerene-Free Organic Solar Cells Exploiting Long-Range Exciton Energy Transfer, in Nature Communications, (pp.1-6).

[8] Meng L., Zhang Y., Wan X., Li C., Zhang X., Wang Y., Ke X., Xiao Z., Ding L., Xia R., Yip H-L., Cao Y., and Chen Y. (2018). Organic and Solution-Processed Tandem Solar Cells with $17.3 \%$ Efficiency, in Science, (pp.10941098).

[9] Reynolds J. R., Thompson B. C., Skotheim T. A. (2019). Handbook of Conducting Polymers, $4^{\text {th }}$ Ed, CRC-Press, Taylor and Francis Group: USA.

[10] Brabec C. J., and Sariciftci N. S., (2000). Polymeric Photovoltaic Devices, in Materials Today, (pp. 5-8).

[11] Susarova D. K., Khakina E. A., Troshin P.A., Goryachev A. E., Sariciftci N.S., Razumov V. F., and Egbe D.A.M. (2011). Photovoltaic Performance of PPE-PPV Copolymers: Effect of the Fullerene Component, in J. Mater. Chem., (pp. 2356-2361).

[12] Vogel A. I. (1989). Vogel's Textbook of Practical Organic Chemistry, fifth ed. Longman, New York. 